\title{
The Crater Lakes of Mt. Kirisima A Limnological Study with Special Reference to Biocoenosis"
}

\author{
By Masuzo Úéno
}

(With 1 plate, 4 text-figures and 7 tables)

Mt. Kirisima in Southern Kyusyu is the generic name for a total of 22 volcanoes forming the so-called "Kirisima volcanic group". These volcanoes are arranged linearly in a NW-SE direction, extending some $13 \mathrm{~km}$. It is remarkable that 15 of them have perfect craters, 8 being filled with water and form. ing picturesque crater lakes. One of these 15 lakes, Mi-ike, is the deepest crater lake in Japan. Three limnological trips to these lakes were made by the present writer together with Dr. S. Yoshimura, the first in February, 1936, the second in July of the same year, on both occasions with a portable rubber-boat, except in the case of Mi-ike, while the third trip was made in February, 1937. With the exception of Mi-ike and Ōnami-ike, these crater lakes were explored limnologically for the first time.

\section{Physiography}

The crater lakes of Mt. Kirisima are divided into two major groups according to their elevation, the first lying at an altitude of from 1200 to $1300 \mathrm{~m}$ and the second being at the south-eastern foot of the mountain about $400 \mathrm{~m}$ above the sea. The morphometric data are summarized in Table $\mathrm{I}$.

1) Contribution from the Ōtsu Hydrobiological Station of the Kyoto Imperial University.

This study was earried out with the aid of grants from the Japan Foundation for the Promotion of Scientific Research, to whose council the writer expresses his cordial thanks. 
Table I

Morphometric Data ${ }^{1}$

\begin{tabular}{|c|c|c|c|c|c|}
\hline Group & Lake & $\begin{array}{c}\text { Altitude of } \\
\text { lake surface } \\
\text { in metres }\end{array}$ & $\begin{array}{c}\text { Diameter } \\
\text { in } \\
\text { metres }\end{array}$ & $\begin{array}{l}\text { Area in } \\
\text { square } \\
\text { metres }\end{array}$ & $\begin{array}{c}\text { Maximum } \\
\text { depth in } \\
\text { metres }\end{array}$ \\
\hline \multirow[t]{6}{*}{$I^{3)}$} & Siratori-ike ${ }^{4)}$ & 1272 & 250 & 43,700 & 0.3 \\
\hline & Rokkannon-ike & 1199 & 440 & 181,000 & 14.1 \\
\hline & Hudō-ilise ... & 1228 & 210 & 29,800 & 9.3 \\
\hline & Ōnami-ike .... & 1239 & 630 & 436,000 & 11.6 \\
\hline & Ōhata-ike .... & 1240 & 565 & 274,000 & 13.8 \\
\hline & Sinmoé-ike.... & 1230 & - & 一 & - \\
\hline \multirow[t]{2}{*}{ II } & Ko-ike.... & 430 & 370 & 50,000 & 16.5 \\
\hline & Mi-ike....... & 305 & 970 & 650,000 & 93.5 \\
\hline
\end{tabular}

Note. 1) Prepared by Yoshimura.

2) Data obtained at high water level in July, 1936.

3) Enumerating from west to east.

4) Or Byakusi-ike.
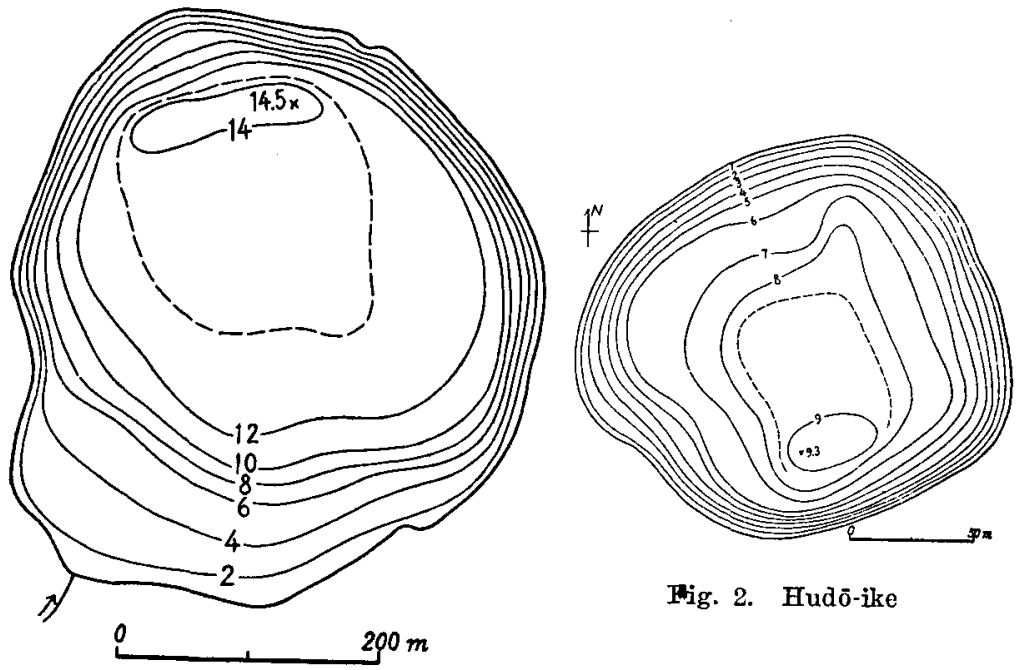

Fig. 2. Hudō-ike

Fig. 1. Rokkannon-ike 
Most of these lakes are circular in outline, their basins having rather large and flat central areas. With the exception of the Mi-ike crater, which is almost completely filled with water, the altitudinal distance from the lake surfaces to the tops of the crater-walls are fairly great, reaching more than $200 \mathrm{~m}$ in the case of the Ōnami-ike crater. With the exception of Rokkannon-ike, which receives its water from Siratori-ike through a small stream, there is no influent in these lakes, neither have they any natural outlets above ground, only Miike and Ōhata-ike discharging by means of aqueducts.

The variation in the water-level (from 2 to $4 \mathrm{~m}$ from year to year) is due to the porous nature of the basins. In July, 1936, they were at an unusually high level owing to the heavy rainfall, but in February, 1937, their surfaces were about 3-4 m lower than in the succeeding year (Plate IV, Figs. 2, 3). These fluctuations seem to bring about marked effects on the development of the shore and certain bottom faunas.

\section{Physical and Chemical Observations ${ }^{2)}$}

In Rokkannon-ike the water is a beautiful blue (Fores's scale No. 3), followed by Hudo-ike, the colour of the others being ForEL's Nos. 4 to 6 . This correlates rather well with the transparency, which is the greatest $(11 \mathrm{~m})$ in Rokkannonike, and from 6-7 $\mathrm{m}$ in the other lakes. In Hudo-ike, even the deepest botton is visible from the boat.

Owing to the fact that the lake surfaces are exposed to strong winds, and because of the clearness of the water, the temperature of the lakes at high elevations in July exceed $19^{\circ} \mathrm{C}$ throughout the bottom, no temperature stratifications being noted. Judging from their surface temperatures, seeing that they are frozen during most winters, although for only

2) Will be discussed in greater detail by Dr. YosHumua in a separate paper. 
very short periods ${ }^{3}$, these lakes may belong to the temperate type. In summer the water in the two lakes at the foot of the mountain is distinctly stratified. They may belong to the tropical type, and may be holomictic (sensu FindenegG 1933, vide also 1937) in that they eirculate only in a severe winter; being usually meromictic (FIndenegG l.c.). This is also proved by the dissolved oxygen content (vide Yoshimura 1936). Although the water of Mi-ike was completely overturned in the very severe winter of 1936 , its $\mathrm{O}_{2}$ content remained at $80 \%$ throughout the bottom $(91 \mathrm{~m})$, while the $\mathrm{O}_{2}$ in the deep water did not reach to more than $57 \%$ in the warm winter of the following year. The water of Ko-ike was completely overturned in the winter of 1937 , but the $\mathrm{O}_{2}$ of its deep water showed only $13 \%$ saturation. In this lake a distinct microstratification of $\mathrm{O}_{2}$ was developed in summer.

The hydrogen-ion concentration of the waters of the lakes shows very interesting variations, as shown in Table II.

Hudo-ike is remarkable for its very strong acid water due to the dissociation of sulphuric acid $\left(\mathrm{SO}_{4} 35.7 \mathrm{mg}\right.$ per litre of

Table II

Hydrogen-ion Concentration

\begin{tabular}{|c|c|c|c|}
\hline \multirow{2}{*}{ Lake } & \multicolumn{2}{|c|}{$\mathrm{pH}$} & \multirow{2}{*}{ Date of Observation } \\
\hline & Surface & Bottom & \\
\hline Hudō-ike ..... & 2.9 & 2.9 & July, 1936 \\
\hline Sinmoé-ike...... & 4.8 & - & February, 1037 \\
\hline Rokkannon-ike .. & 5.8 & 5.9 & July, 1936 \\
\hline Siratori-ike ... & 6.3 & 6.3 & $"$ \\
\hline Ōnami-ike ...... & 6.3 & 6.3 & , \\
\hline ōhata-ike ...... & 6.3 & 6.3 & :, \\
\hline Mi-ike......... & 7.4 & 6.6 & 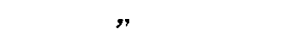 \\
\hline Ko-ike.... & 8.0 & 6.4 & ” \\
\hline
\end{tabular}

3) In the severe winter of 1936 these lakes were frozen over with thieknesses of from 15 to $25 \mathrm{~cm}$ (February $10 \mathrm{th}$ ). 


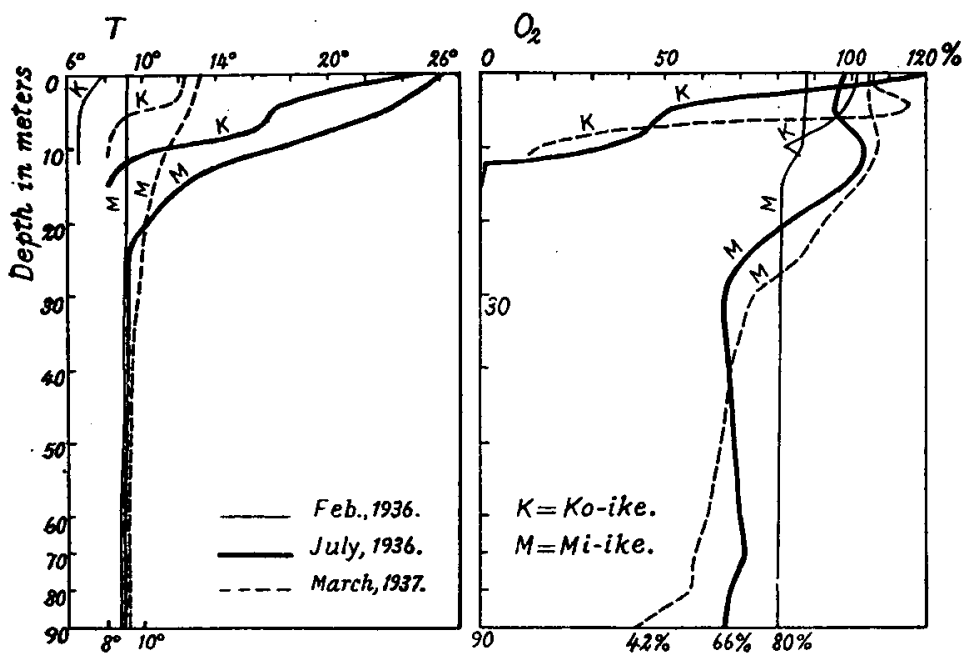

Fig. 3. Temperature and $\mathrm{O}_{2}$ stratifications in the low elevated lakes.

lake water) derived from the sulphur mine east of the lake. With regard to the acidity of the water, this lake ranks fourth among the inorganic acidotrophic lakes in Japan, following Kata-numa $(\mathrm{pH}=1.4)$, Za $\overrightarrow{0}-\mathrm{k}$ ama $(\mathrm{pH}=2.6)$, and Itibisinai-ko $(\mathrm{pH}=2.8)$. The electric conductivity of the water of Hudo-ike is, however, much smaller than that of the other strongly acid water lakes, the $K_{18}$ of its surface water being $4.00 \cdot 10^{-4} \mathrm{ohm}^{-1}$ (total residue $70.4 \mathrm{mg}$ per litre of water). The water of the other Kirisima lakes are said to be very dilute solutions.

\section{Bottom Deposits}

The bottom deposits in most cases are dark grey ooze, which may be designated "Feindetritusgyttja" (sensu LuNDQVIST 1927), containing a large amount of fine mineral particles and, rarely, Difflùgia-testae (in Ōhata-ike). Over the deep bottom of Ko-ike is deposited black sapropel, which gives off the odor of $\mathrm{H}_{2} \mathrm{~S}$. The bottom of Hudō-ike is remarkable in that basal greyish brown mud is covered with $1-2 \mathrm{~cm}$ of soft 
yellow ochre deposit, very rich in pieces of ferric oxide of various sizes. Over this yellow deposit, except for the deepest bottom, a moss, Polytrichum commune $e^{4}$, spread out, making the water appear quite green when viewed from the shore. The bottom deposit of Siratori-ike, the surface of which is covered with Potamogeton frieri, differs somewhat from that of the other lakes, consisting of large quantities of fragments of vegetation.

\section{Bottom Inhabitants}

There is a paucity of species in the bottom fauna, the principal components being a species or two of Chironomidae larvae. The others are larvae of Molanna and Sialis in small numbers, Oligochaetes occurring only in Mi-ike and Ko-ike. The lakes of the first group (Table I) are inhabited chiefly by the larvae of Tanytarsus and Orthocladiinae, with the exception of Siratori-ike, in which the larva of Chironomus connectens (Stenochironomus) abound. The deepest lake, Mi-ike, of the second group is also dominated by Tanytarsus, but Koike differs greatly from the others by the presence of the blood-red larva of Chironomus plumosus.

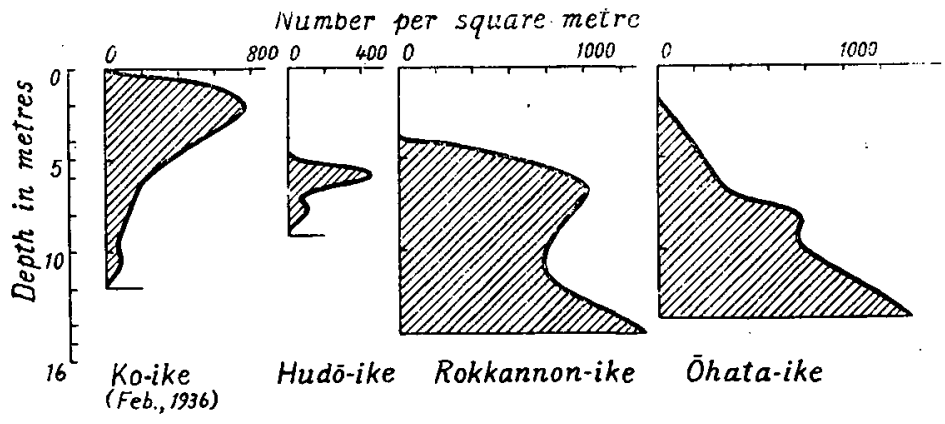

Fig. 4. Distribution of bottom inhabitants with depth.

4) For identifying this species the writer is indebted to Dr. Y. HoRIKAWA of the Hirosina University. 
In July, with the exception of the shallow Siratori-ike, the inhabited areas of the lakes studied are restricted to the bottom at depths exceeding 4-6 $\mathrm{m}$. This almost corresponds to the areas of the mud deposits that are not effected by any changes in water-level. The distribution in July of the number of inhabitants per unit area $\left(\mathrm{n} / \mathrm{m}^{2}\right)$ with depth is roughly divided into two types:

1) $\mathrm{N} / \mathrm{m}^{2}$ diminishes with increase of depth; the largest $\mathrm{n} / \mathrm{m}^{2}$ being at shallow bottom.......Ko-ike ${ }^{5)}$ and Hudō-ike.

2) $\mathrm{N} / \mathrm{m}^{2}$ increases with increase of depth; two large $\mathrm{n} / \mathrm{m}^{2}$ at the middle and the deepest bottom, the latter of which is

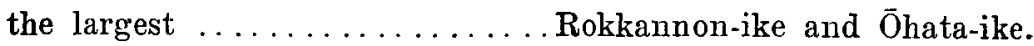

These types are shown in the accompanying figure (p. 187).

The rapid decrease in the inhabitants of Ko-ike with depth may be chiefly due to the sapropelic nature of the deep bottom deposit and to the paucity of $\mathrm{O}_{2}$ in its deep water almost all the year round. The presence of a concentrated zone at a depth of $6 \mathrm{~m}$ in Hudō-ike is difficult to explain. In such strongly acid water, iron, as discussed by OHLE (1935), is dissolved as ions, causing toxic effects upon organisms in the absence of organic substances (vide Uspenski 1927). The bottom water of Hudō-ike contains, however, ionic iron slightly less in quantity than in the surface water (depth $0 \mathrm{~m}, \mathrm{Fe}=$ $0.45 \mathrm{mg} ; 8 \mathrm{~m}, 0.35 \mathrm{mg}$ per litre of water). The abundance of Chironomidae in the middle depths would seem to be due to the amount of fine detritus, which is deposited most abundantly at such depths, rather than to chemical factors.

The bottom inhabitants per unit area in the lakes studied are summarized in Table III.

The largest number, 1550, was found in the deep bottom $(13 \mathrm{~m})$ of Ōhata-ike, no population exceeding 1100 per $\mathrm{m}^{2}$ being

5) According to the conditions that prevailed in February, 1936. In July of the same jear, the bottom inhabitants were concentrated on a bottom only $10-11 \mathrm{~m}$ deep. 
Table III

Bottom Inhabitants

\begin{tabular}{|c|c|c|c|c|c|c|}
\hline \multirow[b]{2}{*}{ Lake } & \multirow{2}{*}{$\begin{array}{c}\text { Number } \\
\text { of } \\
\text { samples }\end{array}$} & \multirow{2}{*}{$\begin{array}{c}\text { Number } \\
\text { of } \\
\text { species } \\
\text { formd }\end{array}$} & \multirow{2}{*}{$\begin{array}{l}\text { Maximum } \\
\text { number } \\
\text { per sq.m. }\end{array}$} & \multicolumn{2}{|c|}{$\begin{array}{l}\text { Average number } \\
\text { per sq. m. }\end{array}$} & \multirow{2}{*}{ Remarks } \\
\hline & & & & Total & $\begin{array}{c}\text { of which } \\
\text { Chironomidae }\end{array}$ & \\
\hline Siratori-ike .. & 5 & 1 & 2550 & 1617 & $1617(100)$ & July \\
\hline Ōhata-ike .... & 9 & 6 & 1550 & 787 & $753 \quad(96)$ & " \\
\hline Rokkannon-ike & 12 & 4 & 1100 & 645 & $616(96)$ & " \\
\hline Ko-ike.... . & 13 & 1 & 396 & 352 & $352(100)$ & ", \\
\hline Hudō-ike & 7 & 2 & 440 & 326 & $326(100)$ & ," \\
\hline Mi-ike........ & 7 & 2 & 132 & 74 & $44 \quad(60)$ & ", \\
\hline Ōnami-ike . & 8 & 2 & 88 & 59 & $59(100)$ & " \\
\hline Ko-ike.... & 12 & 2 & 781 & 281 & $259 \quad(92)$ & Feb. \\
\hline Mi-ike.. & 11 & 2 & 176 & 110 & $110(100)$ & , \\
\hline
\end{tabular}

found in any lake, except in Siratori-ike, where more than 2500 Chironomidae larvae were found in its shallow bottom $(0.5 \mathrm{~m})$. The marked scarcity of bottom fauna in Mi-ike was noticed by MiYad (1932). The order of the lakes according to the average number of bottom inhabitants per unit area seems roughly to correlate with the organic content of their bottom deposits, as will be seen from the annexed table.

Table IV

Total Organic Nitrogen Content ${ }^{\mathrm{I})}$ of the Bottom Muds

\begin{tabular}{c|c|c|c|c|c|c|c}
\hline Lake & $\begin{array}{c}\text { Siratori- } \\
\text { ike }\end{array}$ & $\begin{array}{c}\text { Ohata- } \\
\text { ike }\end{array}$ & Ko-ike & $\begin{array}{c}\text { Rokkannon- } \\
\text { ike }\end{array}$ & $\begin{array}{c}\text { Onami- } \\
\text { ilke }\end{array}$ & $\begin{array}{c}\text { Hudo- } \\
\text { ike }\end{array}$ & Mi-ike \\
\hline $\mathrm{N} \%$ & 1.4 & 1.4 & 1.1 & 0.9 & 0.8 & 0.8 & 0.4 \\
\hline
\end{tabular}

Note. 1) Determined by micro-KJFLdaHL procedure according to Parnas and WAGNER.

\section{Plankton}

No plankton was found in the strongly acid Hudō-ike and Sinmoé-ike. In Rokkannon-ike were found a few Dinobryon in July and Acanthodiaptomus yamanacensis in February. The data for the other lakes are given in Tables V, VI. 
Table V

Number of Zooplankton Species

\begin{tabular}{c|c|c|c|c|c|c}
\hline \hline Plankters & $\begin{array}{c}\text { Onami-ike } \\
\text { (July) }\end{array}$ & $\begin{array}{c}\text { Öhata-ike } \\
\text { (July) }\end{array}$ & $\begin{array}{c}\text { Ko-ike } \\
\text { (July) }\end{array}$ & $\begin{array}{c}\text { Mi-ike } \\
\text { (July) }\end{array}$ & $\begin{array}{c}\text { Mi-ike } \\
\text { (Feb.) }\end{array}$ & $\begin{array}{c}\text { Ko-ike } \\
\text { (Feb.) }\end{array}$ \\
\hline Copepoda.... & 1 & 1 & 1 & 2 & 2 & 1 \\
Cladocera.... & 4 & 3 & 1 & 3 & 2 & 1 \\
Rotatoria.... & 0 & 0 & 7 & 7 & 5 & 5 \\
Total. & 5 & 4 & 9 & 12 & 9 & 7 \\
\hline
\end{tabular}

Table VI

Pereentage Composition of Plankton

\begin{tabular}{|c|c|c|c|c|c|c|}
\hline Plankters & $\begin{array}{c}\text { Ōnami-ike } \\
\text { (July) }\end{array}$ & $\begin{array}{c}\text { Ohata-ike } \\
\text { (July) }\end{array}$ & $\begin{array}{l}\text { Ko-ike } \\
\text { (July) }\end{array}$ & $\begin{array}{r}\text { Mi-ike } \\
\left.\left(J_{u}\right] y\right)\end{array}$ & $\begin{array}{c}\text { Mi-ik } \\
\text { (Feb.) }\end{array}$ & $\begin{array}{l}\text { Ko-ike } \\
\text { (Feb.) }\end{array}$ \\
\hline Copepoda .... & 95.6 & 99.7 & $\begin{array}{r}1 \% 6 \\
15.7\end{array}$ & $\begin{array}{r}18 \\
18.3\end{array}$ & 10.6 & 15.8 \\
\hline Cladocera .... & 4.4 & 0.3 & 23.7 & 26.3 & 66.3 & 6.6 \\
\hline Rotatoria ... & 0 & 0 & 29.4 & 53.2 & 11.6 & 77.5 \\
\hline $\begin{array}{c}\text { Ceratium hirun- } \\
\quad \text { dinella }\end{array}$ & 0 & 0 & 31.2 & 2.2 & 11.5 & 0.1 \\
\hline Total: & 100.0 & 100.0 & 100.0 & 100.0 & 100.0 & 100.0 \\
\hline
\end{tabular}

Ōnami-ike and Ōhata-ike contain no phytoplankton, while in the lakes of lower elevation, Mi-ike and Ko-ike, Ceratium hirundinella is the main component of both winter and summer phytoplankton. The zooplankton of the two former lakes consists largely of intensely red calanoid Acanthodiatomus yamanacensis, which appears in Mi-ike only in winter, and is not so red as in the first mentioned lakes. The winter plankton of Mi-ike differs considerably from that of Ko-ike; its $59.8 \%$ composition consisting of Holopedium gibberum. The Ko-ike plankton is chiefly Conochilus hippocrepis (69.5\% in composition). The summer plankton of these two lakes, however, is similar, being chiefly the rotatorians, Conochilus hippocrepis and Pompholyx complanata.

Comparing the total number of plankton organisms in each lake per unit volume of water in July, Ko-ike is the mosi

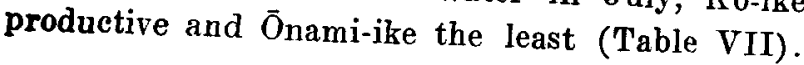


Table VII

Number of Plankters per Cubic Metre of Water

\begin{tabular}{|c|c|c|c|c|c|c|}
\hline Lake & $\begin{array}{l}\text { Depth of } \\
\text { haul in } \\
\text { metres }\end{array}$ & $\begin{array}{l}\text { Total numi- } \\
\text { ber of } \\
\text { plankters }\end{array}$ & $\begin{array}{l}\text { Cope- } \\
\text { poda }\end{array}$ & $\begin{array}{c}\text { Clado- } \\
\text { cera }\end{array}$ & $\begin{array}{l}\text { Rota- } \\
\text { toria }\end{array}$ & $\begin{array}{l}\text { Cera- } \\
\text { tium }\end{array}$ \\
\hline Ko-ike $\ldots \ldots$ & $14.5^{-} 0$ & 11220 & 1790 & 2650 & 3300 & 3480 \\
\hline Mi-ike. . . . . . & $90-0$ & 4860 & 890 & 1280 & 2580 & 110 \\
\hline Ōhata-ike & $13-0$ & 3593 & 3580 & 13 & 0 & 0 \\
\hline Ōnami-ike .... & $10-0$ & 755 & 722 & 33 & 0 & 0 \\
\hline Rokkannon-ike & $14-0$ & 0 & 0 & 0 & 0 & 0 \\
\hline Hudō-ike . & $9-0$ & 0 & 0 & 0 & 0 & 0 \\
\hline Ko-ikel) ...... & $10.5-0$ & 6225 & 980 & 410 & 4830 & 5 \\
\hline$M^{(1-i k e}{ }^{1)} \ldots \ldots$ & $85-0$ & 1230 & 130 & 820 & 140 & 140 \\
\hline
\end{tabular}

Note. 1) February, 1936.

The vertical distribution of plankton was observed only in Mi-ike in February and July, 1936, the results of which will be discussed in detail in another paper. It is to be noted that most of the zooplankters are confined to the epilimnion $\left(22-25^{\circ} \mathrm{C}\right)$ in summer, and that even in winter they are concentrated in the upper strata that are shallower than $15 \mathrm{~m}$.

\section{Characteristics of the Lakes}

Owing to the great scantiness of inflowing waters, the lakes studied, especially those on high elevations, are very poor in nutritive substances. Chemical analyses have failed to show the presence of ammonia-nitrogen in any of the lakes, the nitrogenous compounds being found chiefly in the nitrate state. The water of Rokkannon-ike is the purest, containing 0.01$0.03 \mathrm{mg} P$, and only $0.01 \mathrm{mg}$ nitrate per litre, and having no other forms of nitrogen. Consequently, no marked development of phytoplankton is seen in these lakes, there being only a limited number of species of zooplankters. Of the lakes of low elevation, Ko-ike contains as much as $0.2 \mathrm{mg}$ nitrate per litre.

As to the degree of acidity of the water and the aquatic life in the eight lakes studied, an interesting succession between 
the two extremes is seen, from the very strongly acid Hudo-ike to the almost neutral Ko-ike. The acid water lakes, such as Hudō-ike and Sinmoé-ike are not yet habitable for plankton life, but Rokkannon-ike supports a few plankton organisms. The development of the bottom fauna does not harmonize with plankton production, certain bottom animals even inhabiting Hudō-ike and Rokkannon-ike. In the other lakes vegetable and animal life are permanently established, and the course of their evolution is indicated by certain animals that inhabit them. The bottoms of the high elevated lakes are characterized by Tanytarsus larva, which is usually found in oligotrophic lakes, while in Ko-ike, it is replaced by the larva of Chironomus plumosus. This relationship is more clearly shown by the relative abundance of Acanthodiaptomus yamanacensis. The most suitable habitat for this calanoid is weakly acid and oligotrophic water, such as Ōhata-ike, while water of somewhat advanced eutrophy are not habitable. Ko-ike is in this latter category, Mi-ike standing between the two. From the foregoing discussion, all the lakes of higher elevations may be designated as harmonic oligotrophy (excluding acidotrophy), particularly as pan-oligotrophy sensu PEsta (1929). Ko-ike and Mi-ike are, on the contrary, somewhat advanced toward eutrophy, the former being especially marked in this respect.

Hudō-ike, which is the only acidotrophic lake ("minerogene" sensu Yoshimura 1933, "inorganic" sensu UÉxo 1934) in south-western Japan, presents many interesting problems concerning biocoenosis in idiotrophic waters. In this lake, colonization of the organisms is remarkably inharmonic. Almost the entire bottom is covered with Polytrichum. It is inhabited by two species of Chironomidae larvae, but no plankton organisms occur. Such an extended development of organisms, though very restricted in species, is frequently observed in extremely peculiar habitats, particularly in those with conspicuous chemical factors, such as strongly acid waters, as THrenEmanN 
(1920) has discussed. In this connection, the following three lakes are particularly noteworthy among the 15 known Japanese acidotrophic lakes.

1) Itibisinai-ko $(\mathrm{pH}=2.8)$ in the Southern Kuriles, where occurs abundant plankton (Brachionus urceus only); no bottom inhabitants; production markedly inharmonic.

2) Hudo-ike $(\mathrm{pH}=2.9)$, where there is a considerable growth of a moss (Polytrichum) on the bottom and a small number of bottom-inhabiting animals; no plankton; production inharmonic.

3) Osoresan-ko ( $\mathrm{pH}=3-4$ ) (vide Yoshimura 1934, Masiko 1938), where there is considerable development of vegetable and animal life, at least 6 macroscopic animals, 8 larger aquatic plants, 10 phytoplankters, and 9 zooplankters (KoKuBo et al. 1931, in Japanese). An aquatic moss Leptodictyum spreads over $60 \%$ of the bottom area. A cyprinid fish Tribolodon pharacrocorax is very abundant; the greater part (nearly 9.0\%) of the plankton was represented by a cladoceran Simocephalus vetulus until 1933, but at present Macrocyclops fuscus and Brachionus urceus predominate (Masiko 1938). The bottominhabiting chironomid is Pentaneura monilis of the Tanypodinae. The reason that this lake, notwithstanding its strong acidity, supported such a rich fauna and flora is difficult to explain. In such extreme habitats ${ }^{6}$, age may be one of the important factors, as has been pointed out by Thimeneman (1932).

6) For the biocoenosis of acidotrophic lakes see review by OHLE (1936). 


\section{Literature cited}

FindenegG, I. 1933: Alpenseen ohne Vollzirkulation. Int. Rev. d. ges. Hydr. u. Hydr.28: $29 \overline{-}-311$.

1937: Holomiktisehe und meromiktische Seen. Ibidem. 35: 586-610.

MrYaDI, D. 1932: Studies on the bottom fauna of Japanese lakes VI. Lakes of Southern Kyusyu. Japan. J. Zool. 4, 2: 127-149.

Masiko, K. 1938: Plankton studies on Lake Osoresan. Japan. J. Limnol. $8: 45-52$.

OnLe, W. 1935: Organische Kolloide in ihren Wirkung auf dem Stoffhaushalt der Gewässer. Die Naturwiss. 23: 480-484. 1936: Der Schwefelsaure Tonteich bei Reinbeck. Arch. f. Hydro-
biol. 30: 604-662.

Thienemann, A. 1920: Die Grundlagen der Biocoenotik und Monard's faunistische Prinzipien. Festschr. f. F. Zschoкke, Nr. 4, Basel.

1932: Die Bedeutung des Zeitfaktors für die Besiedlung extremer Lebensstätten. Jenaische Z. f. Naturwiss. 67: 70-79.

UÉno, Masuzo 1934: Acid water lakes in North Shinano. Arch. f. Hydrobiol. 27: $571-584$.

UsPenski, E. E. 1927: Eisen als Faktor für die Verbreitung niederer Wasserpflanzen. KoLkwitz's Pflanzenforschung, Heft 9.

YoshimuRA, S. 1933: Kata-numa, a very strong acid water lake on Volcano Katanuma, Miyagi Prefecture, Japan. Arch. f. Hydrobiol. 26: 197-202.

1934: Anohaline stratification of the chemical constituents of Lake Osoresanko, Aomori Prefecture, Japan. Proc. Imp. Acad. Tokyo, 10: $47 \overline{\mathbf{j}}-478$.

- 1936: A contribution to the knowledge of deep water temperatures of Japanese lakes. Part II. Winter temperatures. Japan. J. Astronomy
\& Geophysies, 14: 57-83. 
Jap. J. Limnology, Vol. 8.

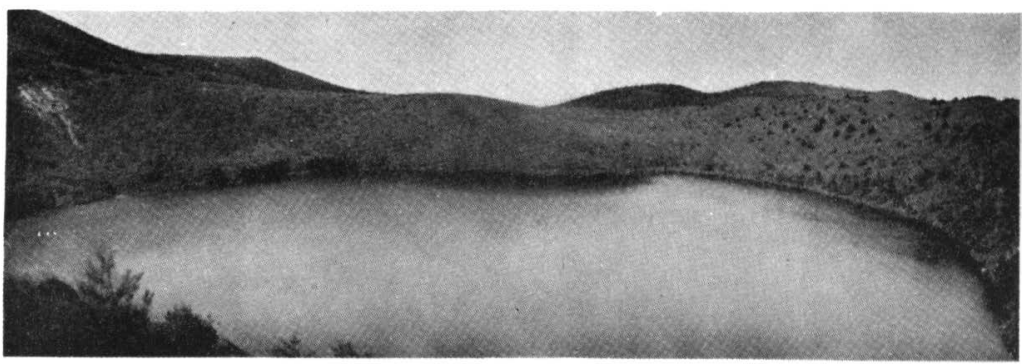

Fig. 1. Hudō-ike (Photo by Uńno).

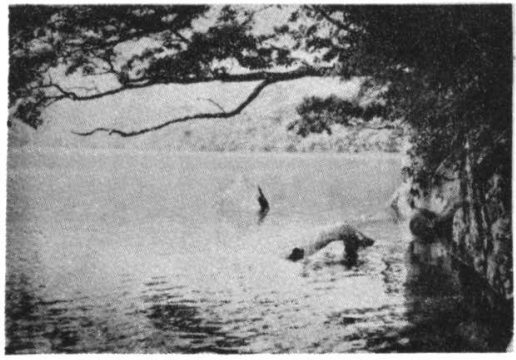

Fig. 2.

Rokkannon-ike.

(July 21, 1936, Photo by UÉno)

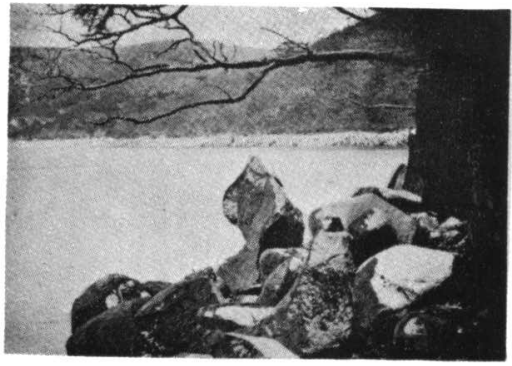

Fig. 3.

Rokkannon-ike.

(February 14, 1937, Photo by Uéno)

M. UÉno: The Crater Lakes of Mt. Kirisima 